\title{
PENGARUH MEDIA PEMBELAJARAN BERBASIS KOMPUTER APLIKASI PAINT TERHADAP KEMAMPUAN KOGNITIF ANAK USIA 4-5 TAHUN DI TK AISYIYAH BUSTANUL ATHFAL 22 BALONGPANGGANG
}

\author{
Wiwit Widiawati \\ Dewi Mayangsari \\ Muhammad Busyro Karim \\ Program Studi Pendidikan Guru Pendidikan Anak Usia Dini Fakultas Ilmu Pendidikan \\ Universitas Trunojoyo Madura \\ email: wiwitwidiawati07@gmail.com
}

Received January 2018, Accepted March 2018, Published April 2018

\begin{abstract}
Influence of Computer Based Learning Media Paint Application to Cognitive Ability of Ages Aged 4-5 Years at Tk Aisyiyah Bustanul Athfal 22 Balongpanggang. The purpose of this study is determine the effect of computer based on the learning of media Paint application forward the cognitive abilities of children A2 TK Aisyiyah Bustanul Athfal 22 Balongpanggang Gresik. Media of learning is everything that is used by teacher to simplify the delivery of learning materials. The media is computer-based learning which has paint application that is used to stimulate the cognitive abilities of children, especially in aspects of learning and problem solving, logical thinking, and symbolic thinking. This research uses quantitative approach that is experimental method with Pre-experimental design research design type one-group pre-test post-test. The subject of this study is a group A children in kindergarten AisyiyahBustanulAthfal 22 Balongpanggang Gresik as many as 11 children. Techniques of collecting data of ths research is participant observation and documentation in the form of photos of activities and plans of daily learning. Data processing uses t-test data analysis. The result of data analysis obtained by Tcount value is $-5,45$ and Ttable value 2,086 then $-t_{\text {table }}>$ $\mathrm{t}_{\text {count }}(-2,086>-5,45)$ and Ha accepted. Based on the data analysis shows there is a significant influence between computer-based learning media paint application to the cognitive abilities of children.
\end{abstract}

Keywords: Computer-Based Learning Media Paint Application, Cognitive Ability, Children Aged 4-5 Years.

\begin{abstract}
Abstrak: Pengaruh Media Pembelajaran Berbasis Komputer Aplikasi Paint Terhadap Kemampuan Kognitif Anak Usia 4-5 Tahun di Tk Aisyiyah Bustanul Athfal 22 Balongpanggang. Tujuan dari penelitian ini untuk mengetahui pengaruh media pembelajaran berbasis komputer aplikasi Paint terhadap kemampuan kognitif anak kelompok A2 TK Aisyiyah Bustanul Athfal 22 Balongpanggang Gresik. Media pembelajaran adalah segala sesuatu yang digunakan guru untuk mempermudah dalam penyampaian materi pembelajaran. Media pembelajaran yang diteliti yaitu media pembelajaran berbasis komputer aplikasi paint yang digunakan untuk menstimulus kemampuan kognitif anak khususnya dalam aspek belajar dan pemecahan masalah, berfikir logis, dan berfikir simbolik. Penelitian ini menggunakan pendekatan kuantitatif dengan menggunakan metode eksperimen dengan desain penelitian Pre-eksperimental Desain jenis one-group pre-tes post-test. Subjek penelitian ini merupakan anak kelompok A di TK Aisyiyah Bustanul Athfal 22 Balongpanggang Gresik sebanyak 11 anak. Teknik pengumpulan data melalui observasi partisipan dan dokumentasi berupa foto-foto kegiatan dan rencana pelaksanaan pembelajaran harian. Pengolahan data menggunakan analisis data uji-t. Hasil

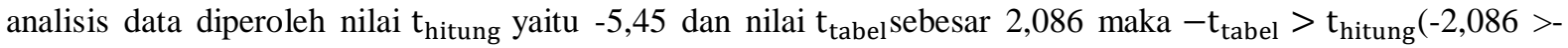
$5,45)$ dan $\mathrm{H}_{\mathrm{a}}$ diterima. Berdasarkan analisis data tersebut menunjukkan terdapat pengaruh yang signifikan antara media pembelajaran berbasis komputer aplikasi paint terhadap kemampuan kognitif anak.
\end{abstract}

Kata Kunci : Media Pembelajaran Berbasis Komputer Aplikasi Paint, Kemampuan Kognitif, Anak Usia 4-5 Tahun.

Pendidikan merupakan suatu alat yang dapat menciptakan Sumber Daya Manusia (SDM) yang berkualitas. SDM yang memiliki nilai karakter bangsa dalam dirinya, sehingga menjadi harapan oleh negara. Untuk mewujudkan hal tersebut haruslah nilainilai ditanamkan sejak dini. Dimana anak usia dini memiliki karakteristik yang unik karena mereka berada pada proses tumbuh kembang yang sangat pesat dan fundamental bagi kehidupan berikutnya. Salah satu upaya yang dapat dilakukan adalah mengikutsertakan anak pada program Pendidikan Anak Usia Dini (PAUD).

PAUD merupakan salah satu bentuk penyelenggaraan pendidikan 
yang menitikberatkan pada peletakan dasar ke arah pertumbuhan dan perkembangan, baik koordinasi motorik (halus dan kasar), kecerdasan emosi, kecerdasan jamak (multiple intelligences), maupun kecerdasan spiritual sesuai dengan keunikan dan pertumbuhan anak usia dini (Suyadi, 2014:22-23). Mengingat PAUD adalah pendidikan pertama bagi anak, maka pentingnya penyelenggaraan pendidikanbagi anak usia dini harus disusun sesuai peraturan yang telah ditetapkan.

Penyelenggaraan pendidikan anak usia dini sebaiknya disesuaikan dengan standar yang ada. Standar tersebut merupakan satu kesatuan yang tidak terpisahkan dalam pengelolaan dan penyelenggaraan pendidikan anak usia dini.Ketika penyelenggaraan PAUD telah sesuai standar, maka dapat berfungsi sebagai dasar dalam perencanaan, pelaksanaan, pengawasan,dan tindak lanjut pendidikan dalam rangka mewujudkan PAUD bermutu. Salah satu standar yang harus dilengkapi sekolah yaitu menurut Peraturan Menteri Pendidikan Nomor 137 Tahun 2014tentang standar sarana dan prasarana Pasal 31 Ayat 1 bahwa sarana dan prasarana merupakan perlengkapan dalam penyelenggaraan dan pengelolaan kegiatan pendidikan, pengasuhan, dan perlindungan anak usiadini.

Sarana dan prasarana merupakan dua komponen yang saling melengkapi dan susah untuk dipisahkan namun memiliki macam yang berbeda. Menurut Suharno dalam Kompri (2008:193) sarana yaitu peralatan dan perlengkapan yang secara langsung dipergunakan dalam menunjang proses pendidikan, terdiri dari buku, Alat Permainan Edukatif, alat tulis, media pembelajaran, sedangkan prasarana adalah fasilitas yang secara tidak langsung menunjang jalannya proses pendidikan, yang terdiri seperti gedung, perpustakaan, toilet, lapangan.

Media pembelajaran merupakan bagian dari salah satu sarana yang ada di sekolah. Peran media dalam pembelajaran di Taman Kanak-Kanak menjadi bagian yang penting mengingat bahwa perkembangan anak pada usia ini berada pada masa konkret. Masa yang menjadi salah satu prinsip pembelajaran di Taman Kanak-Kanak, yang artinya bahwa anak diharapkan dapat mempelajari sesuatu secara nyata. Dengan demikian, pembelajaran di Taman Kanak-Kanak harus menggunakan sesuatu yang memungkinkan anak dapat belajar secara konkret. (Zaman badru, 2012:4.3)

Ragam media pembelajaran yang ada di Taman Kanak-Kanak terdiri dari bermacam-macam dan mulai terjadi pengembangan. Arsyad, A (2011:105) menyatakan bahwa media pembelajaran tersebut meliputi media berbasis visual (meliputi gambar, chart, grafik, transparasi, dan slide), media berbasis audio-visual (video dan audio tape), dan media berbasis komputer (komputer dan video interaktif).Penggunaan berbagai media untuk pembelajaran tidak dapat dihindari dan merupakan salah satu akibat dari berkembangnya ilmu dan teknologi komunikasi.Media yang digunakan sejalan dengan teknologi yang berkembang pada masanya.Bila awal abad 20 media yang digunakan adalah media cetak (karena ditemukannya mesin cetak).Seiring berjalannya waktu berkembang dengan digunakannya radio, film bisu, film bersuara, film berwarna, televisi, video, komputer hingga internet yang muncul di awal abad 21.

Sejak ditemukannya teknologi di bidang informasi yaitu komputer, tujuan pendidikan umumnya dan pembelajaran khususnya semakin mudah dicapai. Pada tahun 1980-an penggunaan komputer di sekolah telah dimulai dan sekarang beberapa sekolah telah memakai internet. 
Perkembangan teknologi yang semakin cepat saat ini membuat media pembelajaran di sekolah juga mengalami pengembangan.Salah satunya yaitu media berbasis komputer.Dimana komputer kini sudah menjadi barang yang wajar di setiap sekolah.

Penggunaan komputer di sekolah bukan hanya pada kepentingan administrasi saja, melainkan kini komputer digunakan untuk membantu guru dalam memudahkan penyampaian materi pembelajaran. Media komputer merupakan media yang menarik bahkan atraktif dan interaktif. Dengan kelebihan yang dimiliki media berbasis komputer, maka guru mengaplikasikan media ini dalam pembelajaran. Krisnadi dalam Marisa (2011: 7.21) Penggunaan media pembelajaran berbasis komputer merupakan cara untuk menghasilkan atau menyampaikan materi dengan menggunakan sumber-sumber yang berbasis mikro prosesor, dimana informasi atau materi yang disampaikan disimpan dalam bentuk digital, bukan dalam bentuk cetakan. Jadi, penyampaian materi yang diberikan oleh guru tidak lagi berbentuk lembar kerja, melainkan melalui program atau aplikasi yang telah dirancang oleh guru dengan disesuaikan pada materi yang akan diajarkan kepada anak sesuai tahapan dan usia anak.

Komputer sebagai media pembelajaran didalamnya terdapat bagian-bagian yang saling berkaitan, misalnya keyboard dapat mengenalkan anak tentang berbagai simbol huruf adan angka. Sesuai dengan pendapat Munir (2010:144) bahwa pembelajaran melalui media komputer sesungguhnya merupakan proses dimana anak perlu dilatih untuk mendekati teks visual seperti sebagaimana anak menguasai huruf dan angka.Ketika anak belajar menggunakan media berbasis komputer dan guru melatih anak untuk menguasai huruf dan angka, maka secara tidak langsung berkembanglah kemampuan kognitif anak.

Perkembangan kognitif anak merupakan salah satu dari enam aspek yang ada di Taman Kanak-Kanak. Aspek aspek tersebut adalah fisik, motorik, bahasa, seni dan kreativitas, serta sosial emosional. Proses kognitif banyak berhubungan dengan berbagai konsep yang telah dimiliki anak dan berkenaan dengan kemampuan berpikirnya dalam memecahkan suatu masalah. (Mulyasa, 2014:25)

Kemampuan berpikir anak atau perkembangan kognitif memiliki tahapan masing masing, menurut tahapan perkembangan kognitif Piaget dalam Beaty (2013:269) terdapat 4 tahapan yaitu sensorimotor, praoperasional, operasional konkrit, operasional formal. Anak usia 4-5 tahun termasuk dalam tahapan praoperasional. Dimana pada usia ini anak menguasai pemikiran simbolis. Anak menggunakan objek untuk menyimbolkan tindakan dan kejadian. Anak belajar menduga efek satu tindakan pada tindakan lain,anak terkecoh oleh tampilan, dananak memikirkan produk akhir.Adapun menurut Peraturan Menteri No. 58 Tahun 2009 bahwa anak usia 4-5 tahun memiliki tingkat pencapaian perkembangan kognitif meliputi tiga aspek yaitu belajar dan pemecahan masalah, berfikir logis, dan berfikir simbolis.

Terdapat banyak hal yang membuat perkembangan kognitif anak meningkat, salah satunya yaitu penggunaan media pembelajaran berbasis komputer.Tak dapat dipungkiri bahwa keduanya ini memiliki hubungan. Menurut Fischer \& Gillespie, bahwa kekuatan komputer adalah kemampuannya menjembatani pemikiran dan pembelajaran konkret dan abstrak. Menurut Conny (2008:56) penggunaan komputer secara cerdas, maka secara reciprocal (timbal balik) komputer juga me-reinforce 
(memperkuat) perkembangan kecerdasan. Komputer mampu memenuhi rasa ingin tahu manusia.Selain itu, kecepatan, kecermatan, keterkinian informasi dapat diperoleh melalui komputer.Dengan demikian, terjadi pengayaan fungsi otak, yang pada gilirannya meningkatkan produksi sel neuroglial, yaitu sel khusus yang mengelilingi sel neuron, sehingga menambah aktivasi sel neuron.

Perkembangan

teknologi

khususnya komputer tidak hanya dinikmati pada kalangan dewasa, tetapi sudah menjamur pada anak usia dini. Akan tetapi mengingat pesatnya perkembangan komputer, masih terdapat sekolah-sekolah terutama di daerah terpencil belum memiliki perangkat komputer dan akses internet yang dapat mendukung program pembelajaran. Mahalnya biaya pembelian komputer, membuat beberapa sekolah menganggap biaya pengadaan komputer di sekolah merupakan biaya yang cukup besar. Sehingga tidak sedikit pihak sekolah yang enggan untuk membeli komputer.

Berdasarkan hasil observasi yang dilakukan pada bulan Juli 2017, peneliti menjumpai kegiatan belajar yang menggunakan media berbasis komputer di TK Aisyiyah Bustanul Athfal 22 Balongpanggang. Kegiatan pembelajaran dengan media berbasis komputer ini mengaplikasikan bermacam-macam software yang dapat mendukung tersampainya isi materi dan tema. Ketika peneliti melakukan observasi dengan guru, pada saat kegiatan pembelajaran, terlihat ada beberapa software yang biasa digunakan oleh guru yaitu, Playlearn, Gcomprise, Dunia Mewarnai, Ginko Paint, Sebran, Ms. Word, Paint. Software tersebut yang sering digunakan oleh guru dalam kegiatan belajar menggunakan media berbasis komputer. Didalam software terdapat pilihan-pilihan kegiatan belajar yang dapat digunakan guru dengan disesuaikan pada rencana pembelajaran harian dan aspek perkembangan anak yang akan dikembangkan.

Banyaknya aplikasi komputer yang dimiliki TK Aisyiyah Bustanul Athfal 22 Balongpanggang membuat guru tidak fokus dalam mengajarkan satu per satu aplikasi tersebut. Di setiap pertemuan pembelajaran, guru mengganti aplikasi yang diajarkan. Namun ketika guru merasa nyaman dengan beberapa aplikasi, maka hanya aplikasi-aplikasi itu saja yang digunakan. Sehingga terdapat aplikasi yang kurang diperkenalkan kepada anak, salah satunya yaitu aplikasi Paint. Akibatnya pada saat anak membuka aplikasi paint, anak belum bisa mengoperasikannya. Terlihat 11 anak dari 19 anak kelompok A2 TK Aisyiyah Bustanul Athfal 22 Balongpanggang belum bisa dan kurang mengenal alipkasi Paint.

Menurut observasi lanjutan yang dilakukan oleh peneliti pada 20 Juli 2017, perkembangan kognitif anak masih belum berkembang sesuai harapan. Contoh aspek berfikir simbolik, kemampuan anak dalam mengenal lambang huruf pada kegiatan menulis "belajar membaca buku" di Ms. Word, terdapat beberapa siswa yang masih belum bisa menuliskannya. Selanjutnya pada aspek berfikir logis, perkembangan anak dalam mengklasifikasikan benda, nampak terdapat siswa yang kesulitan untuk mencari pasangan benda pada saat kegiatan belajar menggunakan komputer aplikasi play learn mix and match. Aspek lain dalam perkembangan kognitif yaitu belajar dan pemecahan masalah, pada tingkat kemampuan mengenal benda berdasarkan fungsi, anak belum mampu untuk mengenali atau menggunakan icon yang ada pada tools program aplikasi yang diajarkan. Jadi, terdapat 11 anak yang kemampuan kognitifnya belum berkembang sesuai harapan dari jumlah keseluruhan siswa kelompok A2 yaitu 19 anak.

Berdasarkan uraian diatas, maka peneliti tertarik untuk mengetahui 
pengaruh media pembelajaran berbasis komputer terhadap perkembangan kognitif anak. Maka judul penelitian ini dirancang sebagai berikut: "Pengaruh Media Pembelajaran Berbasis Komputer Aplikasi PaintTerhadap Kemampuan Kognitif Anak Usia 4-5 Tahun di TK Aisyiyah Bustanul Athfal 22 Balongpanggang Gresik."

\section{Metode Penelitian}

Metode yang dipilih dalam penelitian ini adalah metode penelitian eksperimen. Sugiyono (2013:107) menjelaskan bahwa metode penelitian eksperimen dapat diartikan sebagai metode penelitian yang digunakan untuk mencari pengaruh perlakuan tertentu terhadap yang lain dalam kondisi yang terkendalikan.Penelitian ini menggunakan desain Pre-Experimental Designsdengan jenis penelitian yaitu jenis One-Group Pretest-Posttest Design, dimana dalam penelitiannya terdapat pretest dan posttest yang dilakukan untuk mengetahui dan membandingkan kemampuan kognitif sebelum dan sesudah diberi perlakuan.

Populasi dalam penelitian ini merupakan semua siswa kelompok A2TK AisyiyahBustanulAthfal 22 Balongpanggang yang berjumlah 19 anak. Sedangkan sampel yang representatif atau mewakili dalam penelitian ini yaitu 11 anak dalam kelompok A2 usia 4-5 tahun di TK Aisyiyah Bustanul Athfal Balongpanggang 22 Balongpanggang, Gresik.

Teknik pengumpulan data yang digunakan dalam penelitian yaitu observasi dan dokumentasi. Ditinjau dari katerlibatan pengamatan peneliti menggunakan observasi berperanserta (partisipan). Penelitian ini peneliti menggunakan pedoman observasi dengan daftar check/checklist yang menggunakan 4 opsi yaitu belum berkembang, mulai berkembang, berkembang sesuai harapan, dan berkembang sangat baik. Teknik pengumpulan data selanjutnya yaitu dokumentasi. Teknik ini digunakan untuk mengumpulkan data berupa perangkat pembelajaran seperti hasil karya anak, RPPH, surat keterangan, dan foto-foto proses pembelajaran menggunakan media berbasis komputer yang dilakukan pada kelompok A2 TK Aisyiyah Bustanul Athfal 22 Balongpanggang berlangsung mulai dari pretest, treatment, dan posttest.

Perhitungan analisis data dalam penelitian ini menggunakan uji-t (t-test), tujuan uji t adalah untuk mengetahui ada tidaknya pengaruh atau perbedaan nilai rata-rata antara dua kelompok data yang berpasangan. Penggunaan uji-t dua variabel dapat digunakan dengan rumus sebagai berikut:

$$
t=\frac{\bar{x}_{1}-\bar{x}_{2}}{\sqrt{\frac{s_{1}{ }^{2}}{n_{1}}+\frac{s_{2}{ }^{2}}{n_{2}}-2 r\left(\frac{s_{1}}{\sqrt{n_{1}}}\right)\left(\frac{s_{2}}{\sqrt{n_{2}}}\right)}}
$$

Keterangan:

$\bar{x}_{1}=$ Rata-Rata Pretest

$\bar{x}_{2}=$ Rata-Rata Posttest

$s_{1}=$ Simpangan Baku Pretest

$s_{2}=$ Simpangan Baku Protest

$s_{1}{ }^{2}=$ Varians Pretest

$s_{2}{ }^{2}=$ Varians Posttest

$r=$ Korelasi Antara 2 Sampel

Kriteria penilaian,

jika $-t_{\text {tabel }} \leq t_{\text {hitung }} \leq t_{\text {tabel }}$, maka $\mathrm{H}_{0}$ diterima.

jika $-t_{\text {tabel }}>t_{\text {hitung }}>t_{\text {tabel }}$, maka $\mathrm{H}_{0}$ ditolak.

\section{Hasil dan Pembahasan}

Hasil penelitian dari pengaruh media pembelajaran berbasis komputer aplikasi Paint terhadap kemampuan kognitif anak kelompok A2 di TK Aisyiyah Bustanul Athfal 22 Balongpanggang menjelaskan secara rinci mengenai pengaruh media pembelajaran berbasis komputer aplikasi Paint terhadap kemampuan kognitif anak kelompok A2 di TK Aisyiyah Bustanul Athfal 22 Balongpanggang 
sebelum adanya perlakuan dan sesudah diberi perlakuan. Adapun hasil penelitian ini dapat disajikan dalam tabel berikut:

Tabel 1 Rekapitulasi Hasil Pretest dan Posttest

\begin{tabular}{|c|c|c|c|c|c|}
\hline \multirow[t]{2}{*}{ No } & \multirow[t]{2}{*}{ Nama } & \multicolumn{2}{|c|}{ Pretest } & \multicolumn{2}{|c|}{ Posttest } \\
\hline & & 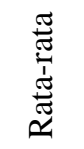 & 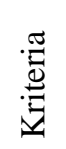 & 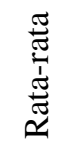 & 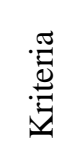 \\
\hline 1 & Anak 1 & 1,96 & MB & 3,13 & BSH \\
\hline 2 & Anak 2 & 1,88 & MB & 2,88 & $\mathrm{BSH}$ \\
\hline 3 & Anak 3 & 1,50 & $\mathrm{BB}$ & 2,38 & MB \\
\hline 4 & Anak 4 & 1,33 & $\mathrm{BB}$ & 2,13 & MB \\
\hline 5 & Anak 5 & 1,88 & MB & 2,92 & $\mathrm{BSH}$ \\
\hline 6 & Anak 6 & 1,79 & $\mathrm{MB}$ & 3,25 & $\mathrm{BSH}$ \\
\hline 7 & Anak 7 & 1,96 & $\mathrm{MB}$ & 2,96 & $\mathrm{BSH}$ \\
\hline 8 & Anak 8 & 1,63 & BB & 2,38 & MB \\
\hline 9 & Anak 9 & 2,17 & $\mathrm{MB}$ & 2,88 & $\mathrm{BSH}$ \\
\hline 10 & Anak 10 & 2,25 & $\mathrm{MB}$ & 3,38 & $\overline{B S H}$ \\
\hline 11 & Anak 11 & 2,08 & $\mathrm{MB}$ & 3,00 & $\mathrm{BSH}$ \\
\hline
\end{tabular}

Berdasarkan tabel 1 diatas maka dapat diketahui bahwa, selama kegiatan Pretest (sebelum perlakuan / treatment) masih terdapat 3 anak masuk dalam kategori belum berkembang (BB), 8 anak masuk dalam kategori mulai berkembang (MB) dan pada kegiatan ini belum ditemukan anak yang masuk dalam kategori berkembang sesuai harapan (BSH) dan berkembang sangat baik (BSB). Sedangkan pada kegiatan posttestmaka dapat diketahui bahwa, perkembangan anak mengalami peningkatan yang signifikan setelah pemberian perlakuan posttest dan terbukti ketika setelah perlakuan anak yang awalnya belum berkembang (BB) mengalami peningkatan menjadi mulai berkembang (MB) dan anak yang awalnya mulai berkembang (MB) mengalami peningkatan menjadi berkembang sesuai harapan (BSH), kesimpulannya bahwa penerapan media pembelajaran berbasis komputer aplikasi Paint terhadap kemampuan kognitif anak berpengaruh dan mengalami perkembangan. Hal ini berdasarkan dari data yang telah diperoleh hasil pretest dan posttest yang telah dilakukan oleh peneliti.

Selain berdasarkan paparan dan hasil tabel dapat juga dibuktikan dari hasil perhitungan yang telah dilakukan peneliti dan dapat diketahui bahwa hipotesis $\left(\mathrm{H}_{0}\right)$ ditolak dan hipotesis alternative $\left(\mathrm{H}_{\mathrm{a}}\right)$ diterima. Hal ini berarti terdapat perbedaan yang signifikan antara sebelum permberian perlakuan media pembelajaran berbasis komputer aplikasi Paint dan sesudah diberikan perlakuan media pembelajaran berbasis komputer aplikasi Paint. Dari perhitungan yang dilakukan peneliti diperoleh nilai $t_{\text {hitung }}$ lebih kecil dari kriteria keputusan yang telah ditetapkan oleh peneliti. Angka thitung yang diperoleh yaitu $-5,45$ dan dibandingkan dengan nilai kriteria keputusan yaitu $t_{\text {tabel }}$ yang berjumlah 2,086. Dapat disimpulkan bahwa nilai $t_{\text {tabel }}$ lebih besar dibandingkan dengan nilai $t_{\text {hitung. }}$. Jika $\left(t_{\text {tabel }}>t_{\text {hitung }}\right)(-2,086>-5,45)$ maka $\mathrm{Ha}$ diterima yang artinya terdapat pengaruh yang signifikan antara penerapan media pembelajaran berbasis komputer aplikasi Paint terhadap kemampuan kognitif anak kelompok A2 TK Aisyiyah Bustanul Athfal 22 Balongpanggang. Jadi media pembelajaran berbasis komputer aplikasi Paint dapat diterapkan untuk menstimulus kemampuan kognitif anak kelompok A2 TK Aisyiyah Bustanul Athfal 22 Balongpanggang.

Berdasarkan hasil perhitungan yang dilakukan dapat diketahui media pembelajaran komputer berbasis aplikasi Paint berpengaruh terhadap kemampuan kognitif anak usia 4-5 tahun. Dengan penggunaan media pembelajaran berbasis komputer aplikasi Paint anak dapat melakukan kegiatan yang dapat mengembangkan kemampuannya mengingat bahwa anak usia dini menurut Wahyudin (2012:7) adalah sosok individu yang sedang menjalani 
suatu proses perkembangan dengan pesat dan sangat fundamental bagi kehidupan selanjutnya. Anak memiliki dunia dan karakteristik sendiri yang jauh berbeda dari orang dewasa. Anak selalu aktif, dinamis, antusias, dan ingin tahu terhadap apa yang dilihat dan didengarnya, seolah-olah tak pernah berhenti belajar. Anak juga bersifat egosentris, memiliki rasa ingin tahu secara alamiah, unik, kaya dengan fantasi, memiliki daya perhatian yang pendek, dan merupakan masa yang paling potensial untuk belajar.

Sesuai dengan pendapat yang dikemukakan diatas mengenai anak usia dini yang ingin tahu terhadap apa yang dilihat dan didengarnya, terlihat ketika kegiatan belajar menggunakan aplikasi paint, anak merasa ingin tahu kegunaan setiap tools yang ada pada aplikasi. Guru memberikan contoh terlebih dahulu kemudian anak mencoba tools tersebut dengan didampingi oleh guru. Mencoba tools pencil, menulis dan mencoret-coret menggunakan tools pencil. Mencoba warna yang ada dalam aplikasi paint. Masa yang paling potensial untuk belajar, terlihat ketika guru memberikan pengarahan mengenai tata cara penggunaan komputer dan aplikasi paint. Anak menyerap informasi yang diberikan oleh guru dan melaksanakan sesuai perintah yang diberikan.

Anak usia dini berbeda dengan orang dewasa. Anak memiliki ciri atau karakteristik tersendiri dan unik. Karakteristik khas yang dimiliki anak pada masa ini merupakan suatu pertumbuhan dan perkembangan yang harus benar-benar dimaksimalkan. Berikut adalah beberapa karakteristik anak usia dini menurut berbagai pendapat, namun dalam pelaksanaan penelitian tidak semua karakteristik tersebut muncul. Adapun beberapa karakteristik yang dijumpai peneliti akan dibahas dan dianalisis sesuai teori dan keadaan lapangan saat penelitian.
Sesuai dengan karakteristik yang pertama ditemui peneliti saat pelaksanaan media pembelajaran berbasis komputer aplikasi paint yaitu unik, Fadlillah (2012:57) berpendapat bahwa sifat anak itu berbeda satu dengan yang lainnya. Anak memiliki bawaan, minat, kapabilitas, dan latar belakang kehidupan masing-masing. Jumlah keseluruhan siswa kelompok A2 TK Aisyiyah Bustanul Athfal 22 Balongpanggang yaitu 19 anak. Masingmasing anak memiliki minat atau kesukaan tersendiri. Terlihat terdapat anak yang suka menulis huruf, ada yang suka menulis angka, dan ada yang suka kegiatan diluar ruangan.

Melihat segi latar belakang kehidupan masing-masing anak berdasarkan cerita dari guru terdapat anak dari keluarga harmonis hingga ada anak yang fatherless. Kemampuan kognitif anak dengan keluarga harmonis dan anak yang fatherlessberbeda cukup signifikan. Hal tersebut nampak ketika peneliti melakukan penelitian di sekolah. Keluarga merupakan pendidikan pertama untuk anak, apa yang diajarkan orangtua dan bagaimana cara mendidiknya akan terbawa di sekolah.

Karakteristik selanjutnya yaitu anak memiliki rasa ingin tahu yang kuat dan antusias terhadap banyak hal. Terlihat ketika guru membuka aplikasi paint yang sebelumnya kurang dicoba oleh anak. Guru mencoba tools yang ada pada aplikasi paint, seperti mewarnai, membuat bentuk, dan menulis. Anak terlihat antusias belajar dan ingin mencoba tools yang dicontohkan guru. Anak memperhatikan dan mempertanyakan tentang kegunaan setiap tools. Hal tersebut sejalan dengan teori Fadlillah (2012:57)bahwa “...anak cenderung memperhatikan membicarakan dan mempertanyakan berbagai hal yang sempat dilihat dan didengarnya, terutama terhadap hal-hal yang baru". 
Bergairah untuk belajar dan banyak belajar dari pengalaman. Hal tersebut diketahui ketika anak belajar menggunakan media pembelajaran berbasis komputer aplikasi paint anak terlihat semangat dalam mencoba aplikasi baru tersebut. Anak belajar dari pengalaman ketika anak menggunakan tools yang salah kemudian memperbaikinya. Anak menulis menggunakan pencils tools, saat menulis terdapat kesalahan sehingga harus menghapusnya menggunakan eraser tools. Dari kesalahan-kesalahan tersebut anak belajar dari pengalaman dan berhati-hati dalam menggunakan tools. Kondisi yang terjadi di lapangan sesuai dengan teori Fadlillah (2012:57) bahwa anak senang melakukan berbagai aktivitas yang menyebabkan terjadinya perubahan tingkah laku pada dirinya. Perubahan yang terjadi yaitu awalnya anak belum bisa atau mampu menjadi bisa dan melakukan kegiatan sendiri.

Semakin menunjukkan minat terhadap teman, menurut Fadlillah (2012:57)“anak mulai menunjukkan untuk bekerja sama dan berhubungan dengan teman-temannya..." Hal tersebut terlihat ketika anak masuk pada ruangan komputer. Tempat duduk komputer yang saling bersebelahan membuat anak bisa saling melihat pekerjaan temannya. Ketika temannya melakukan kesalahan, maka anak yang lainnya membantu temannya memberikan contoh yang benar.

Komputer merupakan satu dari sekian media pembelajaran yang ada di sekolah. Kemunculan komputer ini mampu membantu guru baik dibidang pembelajaran maupun administrasi sekolah. Komputer sebagai suatu perantara komunikasi yang digunakan guru dalam menyampaikan materi pembelajaran memiliki dampak yang dapat menambah pengetahuan dan wawasan anak. Ungkapan tersebut sesuai dengan pendapat yang dikemukakan oleh Gagne dan Briggs dalam Arsyad.A (2011:4) secara implisit mengatakan bahwa media pembelajaran meliputi alat yang secara fisik digunakan untuk menyampaikan isi materi pengajaran, yang terdiri dari antara lain buku, tape recorder, kaset, video kamera, video recorder, film, slide (gambar bingkai), foto, gambar, grafik, televisi, dan komputer.

Setiap media yang digunakan oleh guru memiliki kandungan manfaat. Kandungan manfaat tersebut disesuaikan dengan tujuan pembelajaran yang ingin dicapai pada saat itu. Menurut Sudjana \& Rivai dalam Arsyad.A (2011:24) mengemukakan manfaat media pembelajaran dalam proses belajar anak, yaitu pembelajaran akan lebih menarik perhatian anak sehingga dapat menumbuhkan motivasi belajar anak. Terlihat ketika guru mengkomunikasikan kepada anak mengenai tentang kegiatan belajar menggunakan aplikasi paint. Anak-anak tertarik perhatiannya dan bertanya kepada guru apa itu aplikasi paint. Kemudian guru menjawab dan langsung mempraktekkan aplikasi paint. Sehingga anak termotivasi untuk belajar.

Namun pada saat pengambilan data pretest berlangsung peneliti hanya menggunakan media gambar, guru menjelaskan gambar di depan dan anak mendengarkan apa yang disampaikan guru. Kurangnya interaksi media pembelajaran berupa gambar yang digunakan guru membuat anak mengalami kejenuhan dalam belajar dan akan berpengaruh pada hasil pembelajaran tersebut.Pada pengambilan data pretest secara kumulatif dari kemampuan kognitif dalam aspek belajar dan pemecahan masalah, berfikir logis, dan berfikir simbolik sebelum perlakuan (treatment) menggunakan media pembelajaran berbasis aplikasi Paint secara kumulatif terdapat 3 anak yang tergolong dalam kriteria Belum Berkembang (BB), 8 anak tergolong dalam kategori Mulai berkembang 
(MB)dan sesuai dengan tabel diatas bahwa tidak ada anak yang tergolong dalam kriteria berkembang sesuai harapan (BSH) dan kategori berkembang sangat baik (BSB).

Melihat hasil tersebut sangatlah rendah hal ini diakibatkan karena media pembelajaran yang diterapkan kurang tepat maka anak merasa bosan, dan anak tidak sepenuhnya mendengarkan informasi yang diberikan oleh guru. Sesuai pengamatan observer memang anak terlihat mendengarkan, fokus dan dapat menjawab segala perintah guru namun apa yang diungkap anak tidak didapat dari pengetahuannya sendiri melainkan anak dapat mengungkap atau menjawab pertanyaan yang didapat dari hasil menirukan teman dan guru.

Metode mengajar akan lebih bervariasi, tidak semata-mata komunikasi verbal melalui penuturan kata-kata oleh guru, sehingga siswa tidak bosan dan guru tidak kehabisan tenaga dalam mengajar. Ketika pembelajaran menggunakan media pembelajaran berbasis komputer aplikasi paint, anak melakukan kegiatan praktek langsung. Tugas guru pada pembelajaran kali ini yaitu sebagai fasilitator dan pendamping anak. Jadi tidak seperti kegiatan pretest yang berpusat kepada guru. Siswa hanya pasif mendengar penjelasan dari guru, sehingga anak menjadi bosan dan suasana kelas menjadi gaduh.

Melalui kegiatan praktek langsung pada pelaksanaan treatment anak dapat melakukan lebih banyak kegiatan. Anak belajar berinteraksi dengan komputer menggunakan aplikasi, anak juga melakukan pengamatan ketika mewarnai, menulis, mengganti tools sehingga anak mengetahui perubahan yang terjadi saat pergantian setiap tools. Hal yang dijumpai pada kondisi di lapangan sesuai dengan manfaat yang dikemukakan oleh Sudjana \& Rivai(2011:24) yaitu anak dapat lebih banyak melakukan kegiatan belajar sebab tidak hanya mendengarkan uraian guru, tetapi juga aktivitas lain seperti mengamati, melakukan, memerankan, dan lain-lain.

Penggunaan media pembelajaran dalam kegiatan belajar mengajar memiliki fungsi yang sangat penting untuk mendukung tujuan pembelajaran. Media sebagai perantara akan memudahkan guru ketika penyampaian materi pembelajaran. Namun, dari sekian banyak media yang dijumpai di sekolah memiliki jenis masing-masing. Menurut Heinich, Molenda, \& Russel jenis media pembelajaran salah satunya yaitu "...Computer assisted instructional (pembelajaran berbasis komputer) adalah pemanfaatan komputer untuk pendidikan yang dikenal sering dinamakan pembelajaran dengan bantuan komputer (CAI) dikembangkan dalam beberapa format antara lain drills and practice, tutorial, simulasi, permainan, dan discovery. Komputer telah pula digunakan untuk mengadministrasikan tes dan pengelolaan administrasi sekolah..."

Berdasarkan teori diatas, ragam media pembelajaran yaitu multimedia berbasis komputer yang didalamnya memuat tentang pemanfaatan komputer untuk pendidikan. Pemanfaatan yang dilakukan bukan hanya untuk administrasi sekolah saja, tetapi juga sebagai media pembelajaran. Sesuai dengan pendapat yang telah dikemukakan, TK Aisyiyah Bustanul Athfal $22 \quad$ Balongpanggang menggunakan media pembelajaran berbasis komputer untuk memudahkan guru menyampaikan materi pembelajaran, menarik minat siswa untuk belajar sehingga anak termotivasi dan antusias saat belajar.

Penggunaan komputer sebagai media pembelajaran menurut Ega Rima (2016:68) merupakan proses pembelajaran yang memfungsikan software atau perangkat lunak komputer sebagai media bagi siswa untuk 
berinteraksi dengan komputer dalam aktivitas pembelajaran baik di kelas atau di rumah. Di TK Aisyiyah Bustanul Athfal 22 Balongpanggang dalam kegiatan pembelajaran menggunakan media pembelajaran berbasis komputer memiliki beberapa software yang sering digunakan. Software yang ada di sekolah disesuaikan dengan tujuan pembelajaran yang telah direncanakan. Namun, pada penelitian ini peneliti mengkhususkan pada aplikasi Paint.

Microsoft power paint merupakan salah satu program yang mudah digunakan, mudah diajarkan kepada anak-anak, dan mampu menarik perhatian serta minat anak-anak. Menurut Benny A (2010:9.24) program ini memiliki fasilitas yang ada didalamnya seperti sarana pengolahan gambar, membuat garis lurus, melengkung, lingkaran, memberi warna, dan pengeditan teks. Sejalan dengan pendapat yang dikemukakan oleh diatas yang mengungkapkan bahwa aplikasi paint merupakan aplikasi yang mudah digunakan, terbukti ketika pemberian perlakuan (treatment) anak mampu menjalankan aplikasi paint dengan bantuan instruksi dari guru.

Selain itu anak menggunakan fasilitas yang ada pada aplikasi paint menarik garis lurus saat kegiatan menghubungkan gambar dengan jumlah bilangan sampai 10 , membuat bentuk lingkaran dan persegi dengan berbagai macam ukuran kecil dan besar, memberi warna pada bentuk lingkaran dan persegi yang telah dibuat. Anak mencoba warna yang disukai, anak bebas memilih warna karena dalam aplikasi paint tersedia berbagai macam warna. Pengeditan teks, anak belajar menggunakan keyboard, mengetik huruf, angka dan simbolsimbol lainnya.

Keterlibatan anak dalam belajar memberikan pengalaman yang sangat berharga. Anak akan mulai belajar dari peristiwa yang dialaminya. Anak belajar menggunakan keyboard yang didalamnya memperkenalkan tentang simbol-simbol huruf dan angka. Belajar tentang tools aplikasi paint sehingga anak mengetahui kegunaan dan fungsi dari setiap tools. Belajar mengenal warna, mencoba mengaplikasikan warna. Belajar membuat garis dan berbagai bentuk. Keterlibatan anak saat pemberian perlakuan memberikan pengetahuan baru saat kegiatan belajar yang berdampak pada kemampuannya. Hal tersebut sesuai dengan teori yang dikemukakan oleh Meier dalam Benny A (2010:10.20) bahwa "keterlibatan anak secara langsung dengan obyek yang dipelajari akan memberi dampak yang luar biasa terhadap hasil belajar."

Berbicara tentang hasil belajar anak usia dini terdapat beberapa aspek perkembangan yang dijadikan hasil belajar. Setiap aspek perkembangan yang dinilai berasal dari kemampuan anak yang dilihat oleh guru setiap harinya. Ketika kemampuan yang dimiliki anak itu baik, maka dibalik berkembangnya kemampuan yang dimiliki anak terdapat faktor yang mempengaruhi. Salah satu faktor yang mempengaruhi yaitu adanya media pembelajaran.

Media pembelajaran berbasis komputer memiliki keterkaitan dalam menstimulus perkembangan kognitif anak. Pernyataan ini dapat dibuktikan dengan teori oleh Dina Indriana (2011:99) yang mengungkap bahwa media pembelajaran berbasis komputer penekanannya terletak pada upaya yang berkesinambungan untuk memaksimalkan aktivitas belajar dan mengajar sebagai interaksi kognitif antar siswa, materi pelajaran, dan instruktur dalam hal ini komputer yang telah diprogram. Sistem-sistem yang ada pada komputer menyampaikan pembelajaran secara langsung kepada anak melalui interaksi dengan materi yang telah diprogramkan kepada sistem.

Sesuai dengan yang ditemui di lapangan, interaksi kognitif terjadi saat 
kegiatan belajar menggunakan media komputer. Guru sebagai instruktur atau fasilitator mengarahkan anak dalam menjalankan perintah komputer. Guru menjelaskan maksud dari kegiatan yang dilakukan, membimbing ketika anak salah menekan icon tools. Interaksi kognitif antar teman terlihat ketika anak membantu temannya saat menyelesaikan tugas pada aplikasi paint. Anak membantu temannya menunjukkan huruf atau angka yang benar.

Saat pelaksanaan treatment, anak duduk menghadap komputer masingmasing. Pelaksanaannya yaitu tidak dalam bentuk kelompok, melainkan setiap anak atau perorangan. Hal tersebut dikarenakan guru ingin melihat kemampuan yang dimiliki anak, memaksimalkan waktu belajar anak, melatih konsentrasi anak saat belajar, mengembangkan kemandirian anak sehingga mampu mengerjakan tugasnya sendiri, memaksimalkan pengamatan yang dilakukan guru. Hal tersebut sesuai dengan pendapat Munir (2012:162) yang mengatakan bahwa komputer merupakan media yang dapat membantu anak belajar secara individual.

Berbeda media pembelajaran yang digunakan maka berbeda pula respon yang diberikan anak dan hasil kemampuan yang dicapai. Hal tersebut nampak ketika kegiatan pretest guru menyampaikan materi menggunakan media pembelajaran dengan jenis visual berupa gambar-gambar. Respon yang diberikan anak yaitu terlihat pasif, anak hanya melihat gambar yang dibawa oleh guru mendengar penjelasan yang diberikan guru sehingga anak tidak melakukan suatu kegiatan.

Namun, berbeda ketika guru melakukan treatmen menggunakan media pembelajaran berbasis aplikasi paint, anak terlihat antusias, senang, semangat ingin mencoba mengoperasikan aplikasi. Selain itu anak melakukan kegiatannya sendiri dan didampingi oleh guru atau instruktur.
Melihat hal tersebut sesuai dengan karakteristik media pembelajaran berbasis komputer terdiri dari 5 macam. Masing-masing karakteristik akan dibahas satu persatu sesuai dengan kondisi yang ada dilapangan saat penelitian.

Berdasarkan teori yang dikemukakan Ega Rima (2016:68) bahwa media berbasis komputer memiliki karakteristik efektif. Arti dari efektif menurut teori yang ada yaitu "...media pembelajaran berbasis komputer digunakan harus sesuai dengan tujuan pembelajaran... memiliki keterkaitan dengan materi pembelajaran yang disampaikan sehingga dapat menunjang keberhasilan penyampaian materi pembelajaran". Dikatakan efektif apabila penggunaan media berbasis komputer sesuai dengan tujuan pembelajaran yang akan dicapai. Pada pelaksanaan treatment kegiatan yang diajarkan sesuai dengan tujuan yang ingin dicapai oleh guru dan peneliti. Tujuan tersebut termuat dalam RPPH yang dibuat oleh peneliti dan disetujui oleh guru serta kepala sekolah. Jadi, setiap kegiatan yang dilakukan saat treatment memiliki masing-masing indikator yang ingin dicapai.

Contoh dalam pelaksanaan treatment yang pertama, tujuan yang ingin dicapai peneliti dalam pelaksanaan treatment kali ini yaitu anak mampu menyebutkan bagian-bagian komputer dan mampu menyebutkan macammacam tools yang ada dalam aplikasi paint. Untuk mencapai keefektifan penggunaan media pembelajaran berbasis komputer, guru menggunakan media komputer sebagai perantara dengan cara anak melakukan kegiatan langsung yaitu mengenal, mencoba, dan mengamati setiap bagian-bagian komputer dan macam-macam tools pada aplikasi paint.

Karakteristik yang kedua yaitu menyesuaikan. Dalam teoriEga Rima (2016:68), yang dimaksud 
menyesuaikan adalah "media pembelajaran berbasis komputer digunakan harus sesuai dengan karakteristik anak..." Kegiatan yang diberikan saat treatment telah disesuaikan peneliti dan guru dengan karakteristik anak usia dini dan kemampuan yang akan diamati yaitu kemampuan kognitif. Pada penelitian ini subjek yang digunakan adalah anak kelompok A dengan rentang usia 4-5 tahun. Maka, kegiatan yang dilakukan pun disesuaikan dengan karakteristik anak usia 4-5 tahun dan kemampuan kognitif anak yang tertuang pada Peraturan Menteri Nomor 137 Tahun 2014 Bab III tentang Standar Tingkat Pencapaian Perkembangan Anak usia 45 tahun. Adapun aspek kemampuan kognitif yang diambil dalam penelitian ini yaitu belajar dan pemecahan masalah, berfikir logis, berfikir simbolik.

Karakteristik selanjutnya yaitu interaktif. Karakteristik ini dapat dilihat ketika anak berinteraksi dengan komputer. Bentuk interaksi yang ditampilkan dalam kegiatan treatment yaitu anak mengamati gambar, membuat garis lurus, membuat bentuk, mewarnai, mengetik. Selain anak berinteraksi dengan komputer, anak juga berinteraksi dengan guru sebagai pemandu kelancaran jalannya kegiatan. Pendapat dari Ega Rima (2016:68) menjelaskan bahwa interaktif yang dimiliki komputer adalah "...kemampuan komputer lengkap dalam menampilkan gambargambar, animasi, dan suara yang dapat, menarik perhatian anak.Kelebihan komputer terletak pada kemudahan proses interaksi saat pembelajaran berlangsung..." sesuai dengan kelebihan komputer yang disampaikan teori tersebut terlihat ketika kegiatan saat di sekolah anak mampu, mengerti, dan mudah dalam mengoperasikan aplikasi paint. Sesekali guru memberi instruksi untuk mengarahkan anak.

Karakteristik keempat adalah menarik minat anak. Pada saat pelaksanaan treatment terlihat anak-anak senang dan semangat untuk belajar. Karena pada penggunaan media berbasis komputer ini berbeda dengan media yang biasanya dipakai oleh guru. Minat anak tertarik ketika guru menjelaskan kegiatan yang nantinya akan dapat menulis di komputer, mewarnai di komputer, membuat bentuk dan garis di komputer. Biasanya anak menulis di buku tulis atau kertas. Mewarnai di buku gambar. Dari hal tersebut membuat minat anak tertarik, karena menurut anak biasanya melakukan kegiatan tersebut di buku tulis dan buku gambar namun sekarang melakukan aktivitas tersebut langsung melalui media pembelajaran berbasis komputer.

Berdasarkan karakteristik yang keempat sesuai dengan pendapat Ega Rima (2016:68) bahwa menarik minat anak dapat dilakukan melalui “...penyajian tampilan yang menarik dan berbagai aplikasi dapat digunakan oleh guru untuk menyampaikan materi melalui komputer...Salah satu alasan yang membuat anak senang belajar dengan media komputer adalah tampilan yang tidak monoton..." maka dari itu peneliti menggunakan aplikasi paint karena didalam aplikasi tersebut memuat berbagai kegiatan yang dapat menstimulus kemampuan kognitif dan kreativitas anak.

Karakteristik yang terakhir yaitu terkonsep. Adanya RPPH yang telah dibuat oleh peneliti menjelaskan tentang konsep yang akan dilakukan saat pembelajaran. Namun tidak itu saja, sebelum kegiatan peneliti menyiapkan apa saja aktivitas belajar yang akan dikerjakan oleh anak saat penggunaan media pembelajaran berbasis komputer. Aktivitas belajar disesuaikan dengan indikator yang ingin dicapai. Setelah kegiatan guru melakukan recalling untuk menanyakan perasaan anak dan hasil dari kegiatan yang telah dilakukan. Berdasarkan paparan yang telah dijelaskan diatas terbukti bahwa 
karakteristik yang dimiliki oleh media pembelajaran berbasis komputer sesuai dengan kenyataan yang ada dilapangan pada saat kegiatan treatment.

Mengingat konsep memiliki arti penting dalam pembelajaran yang mencakup pelaksanaan dari awal kegiatan hingga akhir, maka konsep menurut Ega Rima (2016:68) memiliki makna "...selain lebih efektif, pembelajaran menggunakan media komputer juga lebih terkonsep. Pembelajaran yang baik disampaikan dengan konsep yang baik..." saat kegiatan pelaksanaan penelitian, konsep yang dibuat peneliti semuanya telah tertuang pada RPPH. Mulai dari kegiatan awal, kegiatan inti, recalling, hingga penutup.

Media pembelajaran memiliki aneka ragam. Namun tidak semua dapat digunakan dalam pemebelajaran. Guru terlebih dahulu harus mempertimbangkan dan melihat kemampuan yang ingin dicapai. Adanya media pembelajaran berbasis komputer diharapkan dapat membangun situasi yang membantu anak dapat memperoleh pengetahuan, keterampilan dan sikap dalam pembelajaran. Guru menggunakan komputer sebagai media pembelajaran salah satunya untuk mengatasi lambatnya pemahaman anak terhadap konsep materi yang bersifat abstrak.

Sesuai dengan prinsip belajar anak usia dini yang belajar melalui benda konkret, maka media pembelajaran berbasis komputer merupakan salah satu pilihan yang tepat. Media pembelajaran berbasis komputer ini memiliki beberapa fungsi yang perlu dipahami, salah satunya yaitu fungsi kognitif.Komputer mengajarkan mengenai berbagai konsep.Konsep tersebut terdiri dari aturan, prinsip, langkah-langkah, proses, dan kalkulasi.Kemudian, konsep-konsep tersebut dijelaskan dengan sederhana melalui visual dan audio.Dengan demikian, komputer sesuai sebagai media pembelajaran mandiri.Dalam Taksonomi Bloom, Kratwohl, dan Anderson dalam Benny A (2010:11.7) dituliskan bahwa tujuanpada ranah kognitif erat terkait dengan kemampuan berpikir dan kemampuan dalam memberi alasan/ reasoning.

Terdapat banyak hal yang membuat perkembangan kognitif anak meningkat, salah satunya yaitu penggunaan media pembelajaran berbasis komputer.Tak dapat dipungkiri bahwa keduanya ini memiliki hubungan. Menurut Fischer \& Gillespie, bahwa kekuatan komputer adalah kemampuannya menjembatani pemikiran dan pembelajaran konkret dan abstrak. Conny (2008:56) mengemukakan tentang penggunaan komputer secara cerdas, maka secara reciprocal (timbal balik) komputer juga me-reinforce (memperkuat) perkembangan kecerdasan. Komputer mampu memenuhi rasa ingin tahu manusia.Selain itu, kecepatan, kecermatan, keterkinian informasi dapat diperoleh melalui komputer.Dengan demikian, terjadi pengayaan fungsi otak, yang pada gilirannya meningkatkan produksi sel neuroglial, yaitu sel khusus yang mengelilingi sel neuron, sehingga menambah aktivasi sel neuron.

Perkembangan kognitif pada anak-anak dijelaskan dengan teori "interactionist" atau "developmentalist", dalam Soemiarti (2008:27) yang berpendapat bahwa pengetahuan berasal dari interaksi anak dengan lingkungan anak. Sesuai dengan pendapat diatas dapat diselaraskan dengan kenyataan yang ada di lapangan bahwa interaksi yang dilakukan anak dengan komputer dapat menambah pengetahuan anak, mengembangkan kemampuan yang dimilikinya.

Berdasarkan hasil penelitian yang dipadukan dengan teori-teori yang mendukung, perhitungan uji hipotesis menggunakan uji-t mendapat hasil 
Jurnal PG-PAUD Trunojoyo : Jurnal Pendidikan dan Pembelajaran Anak Usia Dini, Volume

bahwa ada pengaruh media pembelajaran berbasis komputer aplikasi Paint terhadap kemampuan kognitif anak kelompok A2 TK Aisyiyah Bustanul Athfal 22 Balongpanggang Gresik.

\section{Kesimpulan}

Penelitian ini mencakup tiga tahap penelitian yaitu pretest, treatment, dan posttest. Hasil pretest menunjukkan bahwa terdapat 3 anak masuk dalam kategori belum berkembang, 8 anak masuk dalam kategori mulai berkembang. Hasil posttest terdapat 3 anak masuk dalam kategori mulai berkembang dan 8 anak masuk dalam kategori berkembang sesuai harapan. Jadi, hasil sebelum perlakuan dan sesudah perlakuan terdapat peningkatan yang signifikan.

Berdasarkan hasil perhitungan analisis data yang dilakukan menggunakan uji-t diperoleh nilai $t_{\text {hitung }}$ sebesar $-5,45$ dan $t_{\text {tabel }}$ sebesar 2,086, maka $-t_{\text {tabel }}$ lebih besar dibanding dengan $t_{\text {hitung }}(-2,086>-$ 5,45). Jadi dapat disimpulkan bahwa jika $-t_{\text {tabel }}>t_{\text {hitung }} \mathrm{H}_{\mathrm{a}}$ diterima dan $\mathrm{H}_{0}$ ditolak yang artinya ada pengaruh signifikan antara penerapan media pembelajaran berbasis komputer aplikasi Paint terhadap kemampuan kognitif anak kelompok A2 TK Aisyiyah Bustanul Athfal 22 Balongpanggang.

\section{DAFTAR PUSTAKA}

Arsyad, A. (2011). Media Pembelajaran. Jakarta: Rajawali Pers.

Beaty, J. (2013).Observasi Perkembangan Anak Usia Dini. Jakarta: Kencana Prenadamedia Group.

Dina, I. (2011). Ragam Alat Bantu Media Pengajaran.Jogjakarta: DIVA Press.
Fadlillah, M. (2012). Desain Pembelajaran Paud. Jogjakarta: Ar-Ruzz Media.

Kompri. (2014). Manajemen Sekolah Teori \& Praktek.Bandung: Alfabeta.

Marisa, dkk. (2011). Komputer dan Media Pembelajaran. Jakarta: Universitas Terbuka.

Munir. (2010). Kurikulum Berbasis Teknologi Informasi Dan Komunikasi. Bandung: Alfabeta. (2012). MULTIMEDIA Konsep \& Aplikasi dalam Pendidikan. Bandung: Penerbit Alfabeta.

Patmonodewo, S. (2008). Pendidikan Anak Prasekolah(Cetakanke-2). Jakarta: PT Asdi Mahasatya.

Pribadi, B. (2010). Komputer dalam Kegiatan Pengembangan Anak Usia Dini (Cetakan ke-5). Jakarta: Universitas Terbuka.

Sanjaya, W. (2012). Media Komunikasi Pembelajaran.Jakarta: Kencana Prenadamedia Group.

Semiawan, R. (2008). Belajar dan Pembelajaran Prasekolah dan Sekolah Dasar.PT. Indeks.

Uyu, W dan Mubiar, A. (2012). Penilaian Perkembangan Anak Usia Dini. Bandung: PT Refika Aditama.

Wati, E. (2016). Ragam Media Pembelajaran.Yogyakarta: Kata Pena.

Permendiknas Nomor 137 Tahun 2014 Tentang Standar Sarana dan Prasarana, Bab 8, Pasal 31, Ayat 1

Kompasiana.com. Mengenalkan Komputer Kepada Anak Usia Dini.

http://googleweblight.com/?lite url=https://www.kompasiana.co m/tasya_amalina14/mengenalka n-komputer-kepada-anak-usiadini_54f98a1ea33311106a8b48f 6\&ei=JYkilqrH\&lc=idID\&geid=33\&s=1\&m=801\&hos $\mathrm{t}=\mathrm{www}$. google.com\&ts=151109 
24 Jurnal PG-PAUD Trunojoyo : Jurnal Pendidikan dan Pembelajaran Anak Usia Dini, Volume 5, Nomor 1, April 2018, hal 10 - 24

5921\&sig=ANTY L3TzFbekbG H60IUDMAsSTUj29CY1A
(Diakses tanggal 3 Februari 2017) 